\title{
Comparing procedures for performing tetrazolium test on carrot seeds
}

\section{Cristina B Lima; Ana C Boaventura; Tamiris T Villela}

Universidade Estadual do Norte do Paraná (UENP), Bandeirantes-PR, Brazil; crislima@uenp.edu.br; ac_boaventura@hotmail.com; tamirisvily@gmail.com

\begin{abstract}
The tetrazolium (TZ) test is one of the main methods to estimate vitality or viability and seed vigor. The aim of this study was to improve the methodology and reduce the execution time of tetrazolium test on carrot seeds, considering two existing references on this subject. Eight lots of 'Brasilia' carrot seeds were used. The hydration, during the pre-conditioning of the seeds, was done in two ways: directly in water during 18 hours and in rolls of filter paper during 2 hours. Seed color was analyzed through combinations between cutting types, concentration, period and temperature used during contact with the $\mathrm{TZ}$ solution. Three types of longitudinal cutting were used, before immersion in the tetrazolium solution: a) lateral and as distant as possible from the embryo distal to the embryo; b) partial, in the distal region opposite to the embryo, on about $1 / 3$ of seed length; c) lateral and near the embryo, without reaching it. The used TZ concentrations were $0.1 ; 0.5$ and $1.0 \%$; periods of contact of the seeds with TZ solution were 1, 2, 6 and 24 $\mathrm{h}$ and temperatures were 30 and $35^{\circ} \mathrm{C}$. The experimental design was completely randomized, with 5 replicates of 20 seeds per lot, per procedure. The results obtained through TZ test were compared with the results obtained in germination and seedling emergence tests. We could make hydration period shorter, from 18 to 2 hours, and staining from 24 to 2 hours. The lateral cutting as close as possible to the embryo, without reaching it, used in preparing the staining, should be emphasized for making execution and interpretation easy. The combination of higher efficiency used for hydration rolls of filter paper during 2 hours and, for staining lateral cutting as close as possible to the embryo, without reaching it, with the development of staining during 2 hours in $0.1 \% \mathrm{TZ}$ solution at $35^{\circ} \mathrm{C}$. Thus, the reduction of the maximum tetrazolium test time, considering hydration ( 18 hours) and staining ( 24 hours), was from 42 to 4 hours and showed to be a feasible and reliable alternative.
\end{abstract}

Keywords: Daucus carota, vegetables, seed viability.

\section{RESUMO}

Comparação de procedimentos para condução do teste de tetrazólio em sementes de cenoura

O teste de tetrazólio (TZ) é um dos principais métodos para estimar a vitalidade ou viabilidade e o vigor de sementes. $O$ objetivo do presente estudo foi aperfeiçoar a metodologia e reduzir o tempo de execução do teste de TZ em sementes de cenoura, a partir de duas referências existentes sobre esse assunto. A pesquisa foi realizada com oito lotes de sementes de cenoura 'Brasília'. A hidratação, durante o pré condicionamento das sementes, foi conduzida de duas maneiras: diretamente em água por 18 horas e em rolos de papel filtro por 2 horas. A coloração das sementes foi analisada por meio de combinações entre tipos de corte, concentração, período e temperatura utilizados durante o contato com a solução de TZ. Foram utilizados três tipos de corte longitudinal prévios à imersão na solução de TZ: a) lateral e mais distante possível do embrião; b) parcial, na região distal oposta ao embrião em cerca de 1/3 do comprimento da semente; c) lateral e próximo ao embrião, sem atingi-lo. As concentrações de TZ empregadas foram 0,1; 0,5 e 1,0\%; os períodos de contato das sementes com a solução de TZ foram de 1, 2, 6 e $24 \mathrm{~h} \mathrm{e}$, as temperaturas foram de 30 e $35^{\circ} \mathrm{C}$. O delineamento experimental foi inteiramente casualizado, com 5 repetições de 20 sementes em cada lote, por procedimento. Os resultados obtidos com o teste de $\mathrm{TZ}$ foram comparados com os obtidos nos testes de germinação e emergência de plântulas. Foi possível abreviar o período de hidratação de 18 para 2 horas e o de coloração de 24 para 2 horas. O corte lateral e mais próximo possível do embrião sem atingi-lo, utilizado no preparo para coloração, merece ser enfatizado pela facilidade na execução e interpretação. A combinação de maior eficiência utilizou para hidratação rolos de papel filtro por 2 horas e, para coloração o corte lateral, o mais próximo possível do embrião, sem atingi-lo, com o desenvolvimento da coloração durante 2 horas na solução de TZ $0,1 \%$ sob $35^{\circ} \mathrm{C}$. Portanto, a redução do tempo máximo de realização do teste de tetrazólio, considerando hidratação (18 horas) e coloração ( 24 horas), foi de 42 para 4 horas e, demonstrou ser uma alternativa exequível e confiável.

Palavras-chave: Daucus carota, hortaliças, viabilidade de sementes.

\section{Received on June 21, 2016; accepted on November 14, 2017}

$\mathrm{C}$ arrots (Daucus carota) are the third most important crop plants, considering volume of seed commercialization in Brazil (Abcsem, 2014). Carrot seeds present lack of uniformity in maturation and size, endosperm filling most of the volume, poorly developed embryo, occupying small cylindrical region, besides tegument presenting single layer of cells (Miranda, 2015). Sowing is performed directly in growing fields, since these plants are not tolerant to transplanting (Filgueira, 2012), which requires high seed quality standard, in order to ensure the desired plant population (Pereira et al., 2007).

The tetrazolium test (TZ), as it is 
fast, accurate and economic testing procedure is one of the main methods to estimate vitality or viability and vigor of seeds, based on the change of color of living tissues, in the presence of 2,3,5-triphenyl tetrazolium chloride, reflecting the activity of dehydrogenase enzyme system. Vitality is mentioned since $\mathrm{TZ}$ does not allow distinguishing dormant seeds from viable seeds (Marcos Filho, 2005).

The efficiency of TZ test depends on the development of appropriate methods for each species, aiming to obtain clear staining, to make the evaluation and the interpretation of conditions of each seed properly. The test usually includes several of the following steps: conditioning (hydration), preparation (cutting, puncturing or removal of teguments), seed staining development and interpretation. Hydration and cutting are necessary, for some species (Brazil, 2009), in order to facilitate enzymatic activation and contact of the tetrazolium solution with the seed tissues, respectively.

For vegetable seeds, instructions for performing tetrazolium test, available for seed analysis (RAS) (Brasil, 2009), exhibit wide variation in preparation time, solution concentration, temperature and staining period. Defining these factors is essential, since they influence the intensity and uniformity of seed staining, and may lead to false or inaccurate results. According to Marcos Filho et al. (1987), such conditions are extremely specific for each species, according to preparation method and permeability of the seed coat. Data interpretation using $\mathrm{TZ}$ test depends on the technique chosen: one lot can be classified as vigorous when using one methodology, and as low vigorous when using another methodology (Lima et al., 2007). According to Barros et al. (2005), the refinement of the TZ test is determined by studies involving comparison with results of other tests such as germination and seedling emergence.

In this context, we can find in scientific literature references which prove the possibility of performing tetrazolium test on vegetable seeds, with lower solution concentration and shorter execution time, when comparing with the procedure established by RAS. The descriptions found in the mentioned references showed efficiencies comparable to germination and vigor tests, such as, Barros et al. (2005), testing zucchini seeds, Bhering et al. (2005) and Nery et al. (2007) testing watermelon seeds, Lima et al. (2007) with melon seeds, Santos et al. (2007) testing tomato, Lima et al. (2010) evaluating cucumber and Gagliardi \& Marcos Filho (2011) testing green pepper seeds.

Some recommendation on how to perform tetrazolium test on carrot seeds can be found in Andrade et al. (1996), AOSA (2002) and Brasil (2009). Such references differ considering seed conditioning, cutting and staining. Andrade et al. (1996) suggest that the seeds remain soaking in moist paper towels, during $2 \mathrm{~h}$ at $25^{\circ} \mathrm{C}$, cutting (Figure $1 \mathrm{~b}$ ), staining in $0.1 \% \mathrm{TZ}$ solution at $35^{\circ} \mathrm{C}$. AOSA (2002) suggests the same about seeds to remain soaking in moist paper towels as Andrade et al. (1996) suggest cutting, time and temperature of conditioning $16 \mathrm{~h}$ at $20-25^{\circ} \mathrm{C}$, though; staining in $0.1 \% \mathrm{TZ}$ solution during $16 \mathrm{~h}$, at $20^{\circ} \mathrm{C}$. To analyze seeds according to Brasil (2009), cutting is similar to the one described in AOSA (2002); for conditioning, seeds are kept in distilled water during 18 hours at $25^{\circ} \mathrm{C}$ and stained in 0.5 and $1.0 \% \mathrm{TZ}$ solution, during 6 and $24 \mathrm{~h}$, at $30^{\circ} \mathrm{C}$.

The differences among the methodologies suggested by the mentioned authors make it difficult to define the procedures to be followed. Information on how the pre-cut and contact of the carrot seeds with the tetrazolium solution should be done allow different interpretations, which can hinder reproduction. Thus, the aim of this study was to improve methodology and reduce the execution time of tetrazolium test, for carrot seeds, indicating appropriate procedures for moisturizing seeds (during preconditioning), for cutting and solution concentration, for temperature and contact time of seedlings in the TZ solution.

\section{MATERIAL AND METHODS}

This study was carried out in the seed analysis laboratory at Universidade Estadual do Norte do Paraná, Campus Luiz Meneghel, Bandeirantes-PR. Eight lots of carrot seeds, cultivar 'Brasília', were used (Table 1), category S2, obtained from a registered company. The seeds were submitted to preliminary analyses of water content determination, tests of seedling germination and emergence, in order to be compared with the results obtained in the two experiments on methodologies of tetrazolium test.

Water content determination drying oven method at $130^{\circ} \mathrm{C}$ during 1 hour, testing two subsamples containing $2.0 \mathrm{~g}$ of seeds of each lot (Brasil, 2009).

Germination test - evaluating four replicates of 50 seeds of each lot, kept under alternated temperature of 20 $30^{\circ} \mathrm{C}$, during 14 days. The evaluations were done on the seventh and tenth days after installation (Brasil, 2009), after that, the number of normal seedlings was registered.

Seedling emergence - four replicates with 36 seeds of each lot were distributed in polypropylene trays (72 cells), filled with commercial substrate Carolina $^{\circledR}$, specific for vegetable seedling production. The trays were kept in a greenhouse (covered with plastic), arch type, and irrigated daily, in the morning and in the afternoon. Seedlings were counted, in the morning, from the first to the fourteenth day after installation, and the number of normal seedlings with expanded cotyledon leaves was recorded. The daily internal temperatures of the greenhouse were verified at 10:00 a.m. and 4:00 p.m., registering an average of $28^{\circ} \mathrm{C}$.

Two experiments were evaluated, using three available references to perform tetrazolium test on carrot seeds. Two references were published by official agencies; the national reference was published by MAPA (Brasil, 2009) and the international by AOSA (2002). The third reference, Andrade et al. (1996), was also included, since this was the only one which is specific for carrot seeds which the authors showed to be 
possible when performing the TZ test, with adaptations in concentration, time and temperature for staining. The three references agreed unanimously upon recommending that carrot seeds can be considered feasible, after permanence time in the $\mathrm{TZ}$ solution, if they show embryo and endosperm completely stained without tolerances in areas of non-stained, flaccid or necrotic tissues.

The experiments I and II were supposed to evaluate procedures to compare the previous cutting, solution concentration and permanence time of the seeds in contact with the tetrazolium solution. The authors used 2, 3, 5-triphenyl tetrazolium chloride $\left(\operatorname{Vetec}^{\circledR}\right)$ dissolved in distilled water, according to the desired concentration. The criteria adopted to classify the carrot seed tissues, in relation to the observed colors in evaluating embryo and endosperm, were classified as pink (showing firm appearance), turgid, shiny and healthy (viable tissue), red showing healthy appearance (viable tissue in a deterioration process) and uncolored with flaccid aspect, total or partially necrotic (unviable tissue). Three types of cutting were used, varying the size of the remaining tissue area (Figure 1).

Experiment I - Concentrations and permanence time in $\mathrm{TZ}$ solution, following the information about the rules for seed analysis 'RAS' (Brasil, 2009), for carrot seeds.

For pre-conditioning, 'RAS' recommend hydration in two ways: considering paper towel or directly in water; hydration in water was chosen for being easy to execute. Thus, the seeds remain immersed in distilled water during 18 hours under constant temperature of $25^{\circ} \mathrm{C}$.

Afterwards, the seeds were prepared for staining using the cutting of Figure 1 and, immersed in tetrazolium solution ( 0.5 and $1.0 \%$ concentrations), during 6 and 24 hours, in the absence of light, at $30^{\circ} \mathrm{C}$. Then, the seeds were immediately removed from the solution, washed in distilled water and evaluated, with the aid of a stereomicroscope.

About the individual evaluation, each seed was sectioned into two parts, along the embryonic axis, and classified according to the colors and visual aspects of the embryo and endosperm tissues. The experimental design was completely randomized, with four treatments: two concentrations ( 0.5 and $1.0 \%)$; two periods of contact in $\mathrm{TZ}$ solution ( 6 and 24 hours), consisting of 5 replicates, twenty seeds on each lot, per procedure.

Experiment II - Cuttings and periods of contact in $\mathrm{TZ}$ solution, based on the methodology described by Andrade et al. (1996). In pre-conditioning, hydration was performed by wrapping the seeds in paper towel (during 2 hours), moistened with distilled water, in the proportion equivalent to 2.5 times the dry paper mass, at constant temperature of $25^{\circ} \mathrm{C}$. Then, the seeds were prepared for staining, varying the cutting and contact time in the TZ solution $(0.1 \%)$ at $35^{\circ} \mathrm{C}$, following three procedures. In the first procedure, the authors used the cutting suggested by Andrade et al. (1996) shown in Figure 1b and, the seeds remained in $\mathrm{TZ}$ solution during

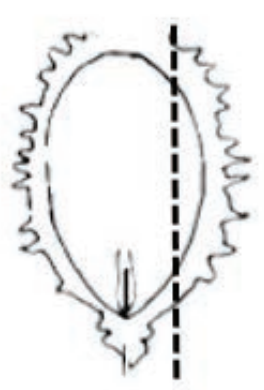

a

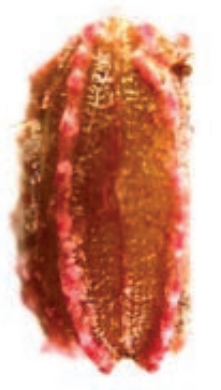

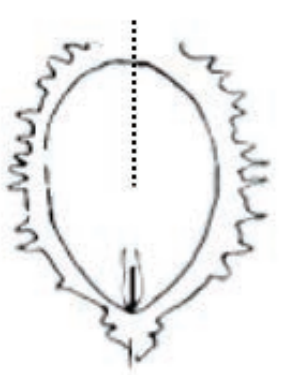

b

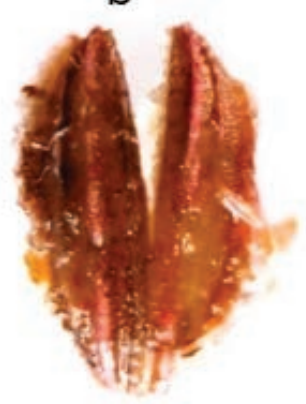

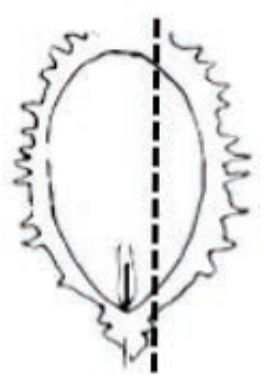

C

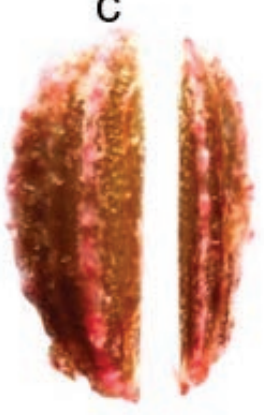

Figure 1. Longitudinal cutting positions of carrot seeds, prior to immersion into the tetrazolium solution: lateral and as distant as possible from the embryo (a); partial, in the opposite side of the embryo at about 1/3 of the length (b); lateral and close to the embryo, without reaching it (c). Bandeirantes, UENP, 2016.

a

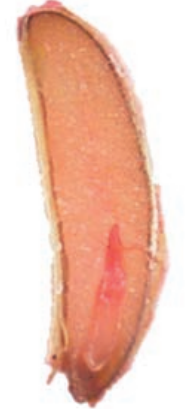

b

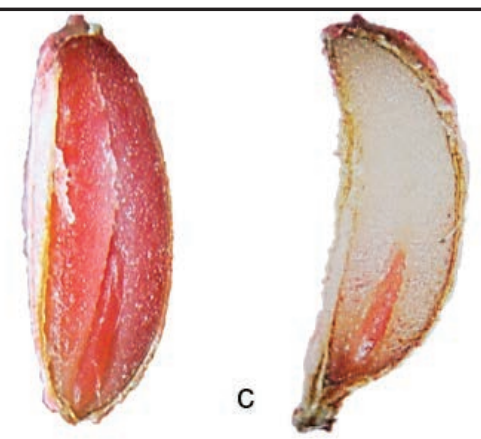

d

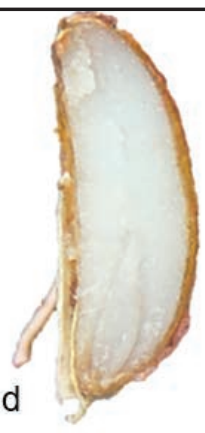

Figure 2. Staining observed in carrot seeds after the exposure to tetrazolium solution: pink (a), red (b), only pink embryo (c) and uncolored (d). Bandeirantes, UENP, 2016. 
1 hour. In the second procedure, the authors adapted the cutting in Figure 1a, described in 'RAS' (Brasil, 2009), for the cutting represented in Figure $1 \mathrm{c}$ and, the seeds remained 1 hour in $\mathrm{TZ}$ solution. In the third procedure, the authors used the cutting represented in Figure $1 \mathrm{c}$ again and the seeds remained in $\mathrm{TZ}$ solution during 2 hours.

After the staining periods, the seeds were taken out from the TZ solution, washed with distilled water and immediately analyzed, with the aid of a stereomicroscope. In the individual evaluation, each seed was sectioned into two parts along the embryonic axis, and classified according to the colors and visual aspects of the embryo and endosperm tissues.

The experimental design was completely randomized, with three treatments: cutting Figure $1 \mathrm{~b}$ for 1 hour; cutting Figure 1c for 1 hour, cutting Figure 1c for 2 hours, consisting of 5 replicates of twenty seeds of each lot, per procedure.

Statistical analysis - The data obtained in the experiments were transformed into $\sqrt{\mathrm{x}+0,5}$, submitted to the variance analysis and means were grouped by the Scott-Knott grouping test, at a level of $5 \%$ probability.

\section{RESULTS AND DISCUSSION}

\section{Experiment I}

The pink-colored seeds (\%), with viable tissue (Figure 2a), did not differ according to the procedures used in this study (Table 2). The percentage of non-stained seeds, considered unviable (Figure 2d), observed in a period of 6 hours, was similar for both concentrations, except for lot 2 (Table 2). However, attesting the period of 24 hours, this percentage decreased at the same time the percentage of red-colored seeds increased. However, these seeds showed firm and shiny tissues, not being appropriate to classify them as deteriorated, only due to the coloration (Figure 2b).

The authors highlighted that redcolored seeds were observed only during the 24-hour period in contact with tetrazolium solution, regardless of

Table 1. Characterization of eight carrot seed lots according to germination (GR), reported on the packaging labels, as well as water content (TA) and preliminary germination tests in laboratory (GL) and seedling emergence tests (EP). Bandeirantes, UENP, 2016.

\begin{tabular}{lrrrrrrrr}
\hline $\begin{array}{l}\text { Characteristics } \\
(\%)\end{array}$ & $\mathbf{1}$ & \multicolumn{1}{c}{$\mathbf{2}$} & \multicolumn{1}{c}{$\mathbf{3}$} & $\mathbf{4}$ & $\mathbf{5}$ & $\mathbf{6}$ & $\mathbf{7}$ & $\mathbf{8}$ \\
\hline GR & 80.0 & 84.0 & 86.0 & 80.0 & 80.0 & 83.0 & 86.0 & 83.0 \\
TA & 7.3 & 6.7 & 7.4 & 6.3 & 6.8 & 7.3 & 6.5 & 6.6 \\
GL & 74.0 & 72.0 & 78.5 & 66.5 & 75.5 & 81.0 & 79.5 & 81.0 \\
EP & 69.4 & 81.9 & 67.3 & 67.3 & 63.1 & 84.7 & 72.2 & 68.7 \\
\hline
\end{tabular}

Table 2. Average percentages of eight lots of pink-colored, red-colored or uncolored carrot seeds after two combinations of concentration and contact time in tetrazolium solution. Bandeirantes, UENP, 2016.

\begin{tabular}{|c|c|c|c|c|c|c|c|c|}
\hline \multirow{2}{*}{$\begin{array}{l}\text { Contact time / } \\
\text { concentration }\end{array}$} & 1 & 2 & 3 & 4 & 5 & 6 & 7 & 8 \\
\hline & \multicolumn{8}{|c|}{ Pink } \\
\hline $6 \mathrm{~h} / 0,5 \%$ & $69.0 \mathrm{a}^{1}$ & $71.0 \mathrm{a}$ & $66.0 \mathrm{a}$ & $69.0 \mathrm{a}$ & $65.0 \mathrm{a}$ & $77.0 \mathrm{a}$ & $76.0 \mathrm{a}$ & $74.0 \mathrm{a}$ \\
\hline $6 \mathrm{~h} / 1,0 \%$ & $64.0 \mathrm{a}$ & $81.0 \mathrm{a}$ & $65.0 \mathrm{a}$ & $71.0 \mathrm{a}$ & $78.0 \mathrm{a}$ & $70.0 \mathrm{a}$ & $75.0 \mathrm{a}$ & $76.0 \mathrm{a}$ \\
\hline $24 \mathrm{~h} / 0,5 \%$ & $63.0 \mathrm{a}$ & $70.0 \mathrm{a}$ & $61.0 \mathrm{a}$ & $60.0 \mathrm{a}$ & $70.0 \mathrm{a}$ & $71.0 \mathrm{a}$ & $67.0 \mathrm{a}$ & $67.0 \mathrm{a}$ \\
\hline $24 \mathrm{~h} / 1,0 \%$ & $66.0 \mathrm{a}$ & $67.0 \mathrm{a}$ & $54.0 \mathrm{a}$ & $57.0 \mathrm{a}$ & $66.0 \mathrm{a}$ & $73.0 \mathrm{a}$ & $79.0 \mathrm{a}$ & $68.0 \mathrm{a}$ \\
\hline \multirow[t]{2}{*}{ CV (\%) } & \multicolumn{8}{|c|}{6.98} \\
\hline & \multicolumn{8}{|c|}{ Red } \\
\hline $6 \mathrm{~h} / 0,5 \%$ & $0.0 \mathrm{~b}$ & $0.0 \mathrm{c}$ & $0.0 \mathrm{c}$ & $0.0 \mathrm{c}$ & $0.0 \mathrm{c}$ & $0.0 \mathrm{~b}$ & $0.0 \mathrm{~b}$ & $0.0 \mathrm{~b}$ \\
\hline $6 \mathrm{~h} / 1,0 \%$ & $0.0 \mathrm{~b}$ & $0.0 \mathrm{c}$ & $0.0 \mathrm{c}$ & $0.0 \mathrm{c}$ & $0.0 \mathrm{c}$ & $0.0 \mathrm{~b}$ & $0.0 \mathrm{~b}$ & $0.0 \mathrm{~b}$ \\
\hline $24 \mathrm{~h} / 0,5 \%$ & $13.0 \mathrm{a}$ & $14.0 \mathrm{a}$ & $9.0 \mathrm{~b}$ & $24.0 \mathrm{a}$ & $5.0 \mathrm{~b}$ & $20.0 \mathrm{a}$ & $12.0 \mathrm{a}$ & $11.0 \mathrm{a}$ \\
\hline $24 \mathrm{~h} / 1,0 \%$ & $11.0 \mathrm{a}$ & $7.0 \mathrm{~b}$ & $22.0 \mathrm{a}$ & $6.0 \mathrm{~b}$ & $20.0 \mathrm{a}$ & $16.0 \mathrm{a}$ & $4.0 \mathrm{~b}$ & $17.0 \mathrm{a}$ \\
\hline \multirow[t]{2}{*}{ CV (\%) } & \multicolumn{8}{|c|}{37.9} \\
\hline & \multicolumn{8}{|c|}{ Uncolored } \\
\hline $6 \mathrm{~h} / 0,5 \%$ & $31.0 \mathrm{a}$ & $29.0 \mathrm{a}$ & $34.0 \mathrm{a}$ & $31.0 \mathrm{a}$ & $35.0 \mathrm{a}$ & $23.0 \mathrm{a}$ & $24.0 \mathrm{a}$ & $26.0 \mathrm{a}$ \\
\hline $6 \mathrm{~h} / 1,0 \%$ & $36.0 \mathrm{a}$ & $19.0 \mathrm{~b}$ & $35.0 \mathrm{a}$ & $29.0 \mathrm{a}$ & $22.0 \mathrm{a}$ & $30.0 \mathrm{a}$ & $25.0 \mathrm{a}$ & $24.0 \mathrm{a}$ \\
\hline $24 \mathrm{~h} / 0,5 \%$ & $24.0 \mathrm{~b}$ & $16.0 \mathrm{~b}$ & $30.0 \mathrm{a}$ & $16.0 \mathrm{~b}$ & $25.0 \mathrm{a}$ & $9.0 \mathrm{~b}$ & $21.0 \mathrm{a}$ & $22.0 \mathrm{a}$ \\
\hline $24 \mathrm{~h} / 1,0 \%$ & $23.0 \mathrm{~b}$ & $26.0 \mathrm{a}$ & $24.0 \mathrm{a}$ & $37.0 \mathrm{a}$ & $14.0 \mathrm{~b}$ & $11.0 \mathrm{~b}$ & $17.0 \mathrm{a}$ & $15.0 \mathrm{a}$ \\
\hline CV (\%) & \multicolumn{8}{|c|}{17.6} \\
\hline
\end{tabular}

${ }^{1}$ Averages followed by the same letter in the column do not differ by the Scott-Knott test, $5 \%$.

their concentration (Table 2), showing that the longest exposure period was responsible for this result, and may not characterize the actual physiological condition of these seeds. This result differs from that one obtained by Delouche et al. (1976), with respect to the difference in coloration speed, between vigorous tissues and damaged and/or deteriorated seeds. These authors reported that vigorous tissues color slowly and uniformly, differently from the damaged and/or deteriorated ones, which generally color faster and develop red-carmine color.

According to Marcos Filho (2005), coloration is important as an indicator of tissue viability, since possible deviations are recognized, which means, colorations which are darker and weaker than the regular intensity. This can characterize deterioration or inviability of the tissue, as well as, the excessive or insufficient period of contact with the tetrazolium solution. Darker colors can reflect an increase of solution concentration or the period of the staining development; however the darker the seed color after the contact with the tetrazolium solution, the greater the difficulty to differentiate tissues and identify injuries, being possible to confuse vigorous tissues 
Table 3. Average values of eight carrot seed lots (\%) distributed in categories of tetrazolium staining test, after three procedures, varying periods (hours) of contact time in solution and cutting positions. Bandeirantes, UENP, 2016.

\begin{tabular}{lrrrrrrrr}
\hline Period/ & $\mathbf{1}$ & $\mathbf{2}$ & $\mathbf{3}$ & $\mathbf{4}$ & $\mathbf{5}$ & $\mathbf{6}$ & $\mathbf{7}$ & $\mathbf{8}$ \\
\cline { 2 - 8 } cutting & \multicolumn{7}{c}{ Endosperm and pink embryo } \\
\hline $1 \mathrm{~h} / \mathrm{b}^{*}$ & $0.0 \mathrm{~b}^{1}$ & $0.0 \mathrm{~b}$ & $0.0 \mathrm{~b}$ & $0.0 \mathrm{~b}$ & $0.0 \mathrm{~b}$ & $0.0 \mathrm{~b}$ & $0.0 \mathrm{~b}$ & $0.0 \mathrm{~b}$ \\
$1 \mathrm{~h} / \mathrm{c}$ & $0.0 \mathrm{~b}$ & $0.0 \mathrm{~b}$ & $0.0 \mathrm{~b}$ & $0.0 \mathrm{~b}$ & $0.0 \mathrm{~b}$ & $0.0 \mathrm{~b}$ & $0.0 \mathrm{~b}$ & $0.0 \mathrm{~b}$ \\
$2 \mathrm{~h} / \mathrm{c}$ & $83.0 \mathrm{a}$ & $79.0 \mathrm{a}$ & $77.0 \mathrm{a}$ & $80.0 \mathrm{a}$ & $82.0 \mathrm{a}$ & $78.0 \mathrm{a}$ & $81.0 \mathrm{a}$ & $83.0 \mathrm{a}$ \\
\hline $\mathrm{CV}(\%)$ & \multicolumn{7}{c}{ Uncolored } \\
\hline \multicolumn{7}{c}{5.13} \\
\hline $1 \mathrm{~h} / \mathrm{b}$ & $88.0 \mathrm{a}$ & $89.0 \mathrm{a}$ & $93.0 \mathrm{a}$ & $88.0 \mathrm{a}$ & $83.0 \mathrm{a}$ & $84.0 \mathrm{a}$ & $90.0 \mathrm{a}$ & $90.0 \mathrm{a}$ \\
$1 \mathrm{~h} / \mathrm{c}$ & $36.0 \mathrm{~b}$ & $35.0 \mathrm{~b}$ & $45.0 \mathrm{~b}$ & $39.0 \mathrm{~b}$ & $28.0 \mathrm{~b}$ & $34.0 \mathrm{~b}$ & $30.0 \mathrm{~b}$ & $33.0 \mathrm{~b}$ \\
$2 \mathrm{~h} / \mathrm{c}$ & $17.0 \mathrm{c}$ & $21.0 \mathrm{c}$ & $23.0 \mathrm{c}$ & $20.0 \mathrm{c}$ & $18.0 \mathrm{~b}$ & $22.0 \mathrm{~b}$ & $19.0 \mathrm{c}$ & $17.0 \mathrm{c}$ \\
\hline $\mathrm{CV}(\%)$ & \multicolumn{7}{c}{12.47} \\
\hline \multicolumn{7}{c}{ Pink embryo } \\
\hline $1 \mathrm{~h} / \mathrm{b}$ & $12.0 \mathrm{~b}$ & $11.0 \mathrm{~b}$ & $7.0 \mathrm{~b}$ & $12.0 \mathrm{~b}$ & $17.0 \mathrm{~b}$ & $16.0 \mathrm{~b}$ & $10.0 \mathrm{~b}$ & $10.0 \mathrm{~b}$ \\
$1 \mathrm{~h} / \mathrm{c}$ & $64.0 \mathrm{a}$ & $65.0 \mathrm{a}$ & $55.0 \mathrm{a}$ & $61.0 \mathrm{a}$ & $72.0 \mathrm{a}$ & $66.0 \mathrm{a}$ & $70.0 \mathrm{a}$ & $67.0 \mathrm{a}$ \\
$2 \mathrm{~h} / \mathrm{c}$ & $0.0 \mathrm{c}$ & $0.0 \mathrm{c}$ & $0.0 \mathrm{~b}$ & $0.0 \mathrm{c}$ & $0.0 \mathrm{c}$ & $0.0 \mathrm{c}$ & $0.0 \mathrm{c}$ & $0.0 \mathrm{c}$ \\
\hline $\mathrm{CV}(\%)$ & \multicolumn{7}{c}{19,46} \\
\hline
\end{tabular}

${ }^{1}$ Averages followed by the same letter in the column do not differ by the Scott-Knott test, $5 \%$; ${ }^{*}$ Cuting as shown in figure $1 ;{ }^{2}$ The embryo colored in pink tone and the endosperm remained uncolored.

with those of less vigor (Marcos Filho et al., 1987).

The TZ solution concentration $(0.5$ and $1.0 \%)$ did not influence, significantly, the average percentages obtained for pink color (Table 2), even during the longest contact time (24 hours). Thus, considering carrot seeds, the contact time compared to the increase of the solution concentration exerted a greater influence on the results obtained in the TZ test. In this context, the lowest concentrations are better as they favor the color identification and physiological conditions of the evaluated seed tissues, and also because it reduces the salt taste.

\section{Experiment II}

The highest percentage of uncolored seeds (Figure 2d) was observed when the authors used the cutting of Figure $1 \mathrm{~b}$, soaking in $\mathrm{TZ}$ solution for 1 hour (Table 3 ). When the authors allied 1 hour of contact time in $\mathrm{TZ}$ solution, varying the cutting for Figure 1c, a highest percentage of seeds was observed where only the embryo was colored (Figure 2a). The preparation, combining the lateral cutting and close to the embryo, without reaching it (Figure 1c), remaining 2 hours in the TZ solution was the most appropriate, since this is the only one which fits the information of AOSA (2002) and of RAS (Brasil, 2009), in which, to classify carrot seeds as viable, the endosperm and embryo axis tissues should be totally colored.

Andrade et al. (1996) tested TZ on carrot seeds, soaked during $2 \mathrm{~h}$ at $25^{\circ} \mathrm{C}$, cutting as represented in Figure 1b, remaining the seeds in $0.1 \% \mathrm{TZ}$ solution at $35^{\circ} \mathrm{C}$ during 1 hour; they obtained high percentage of viable seeds, but did not show any reference or explanation about the adopted criterion to classify viable seeds.

Concerning the time necessary for seed coloration, in the shortest period of 6 hours (evaluated in the experiment I) and 1 and 2 hours (experiment II), permitted the observation of only pinkcolored seeds, showing that viable carrot seeds need shorter permanence time in TZ solution for staining (Table 2).

The average of viable seeds (\%) obtained in the tetrazolium test, using the cutting of Figure $1 \mathrm{c}$ and 2 hours of contact with $\mathrm{TZ}$ solution, differed in $4.9 \%$ when compared to the immersion in TZ solution during 6 and 24 hours, using the cutting of Figure 1a, considering that, when comparing with the germination test, the difference was $4.4 \%$ (Figure 3 ). This result shows that the viable carrot seeds need a shorter contact time in the $\mathrm{TZ}$ solution for coloration. According to RAS (Brasil, 2009), the accuracy of the TZ test is evaluated comparing with the results of the germination test, considering that for carrot seeds, differences up to $5 \%$ between the results of both tests are acceptable. Barros et al. (2005), testing zucchini seeds and Lima et al. (2010), for cucumber seeds, also reported the association between germination test and the results of viability by the TZ test. The highest difference was observed in relation to the emergence test $(8.5 \%)$, whose seedling development capacity, after germination up to the expansion of the cotyledon leaves, above the surface of the substrate, determines the result of the evaluation.

Comparing the recommendations for the TZ test available in RAS (Brasil, 2009), the lateral cutting and as close as possible to the embryo without reaching it, used for preparing the coloration, should be emphasized since it facilitates execution and interpretation. This cutting allowed shortening the contact time of the seeds in the TZ solution, from 24 hours, maximum period of time recommended by RAS (Brasil, 2009), to 2 hours. The authors highlight that the preconditioning time from 18 hours, recommended by RAS (Brasil, 2009), can also be surely reduced to 2 hours, according to the period suggested by Andrade et al. (1996). Thus, it is possible to perform $\mathrm{TZ}$ test on carrot seeds in 4 hours, without damaging its efficiency and reliability. This reduction can be justified by the size and speed of immersion of carrot seeds, since according to Rodo et al. (2000), small seeds, like that one of carrots, absorb water faster in comparison to big seeds. In relation to conditioning time, Marcos Filho (2005) explains that hydration time is necessary to facilitate cutting and to activate enzymatic metabolism, and it should be as short as possible. 


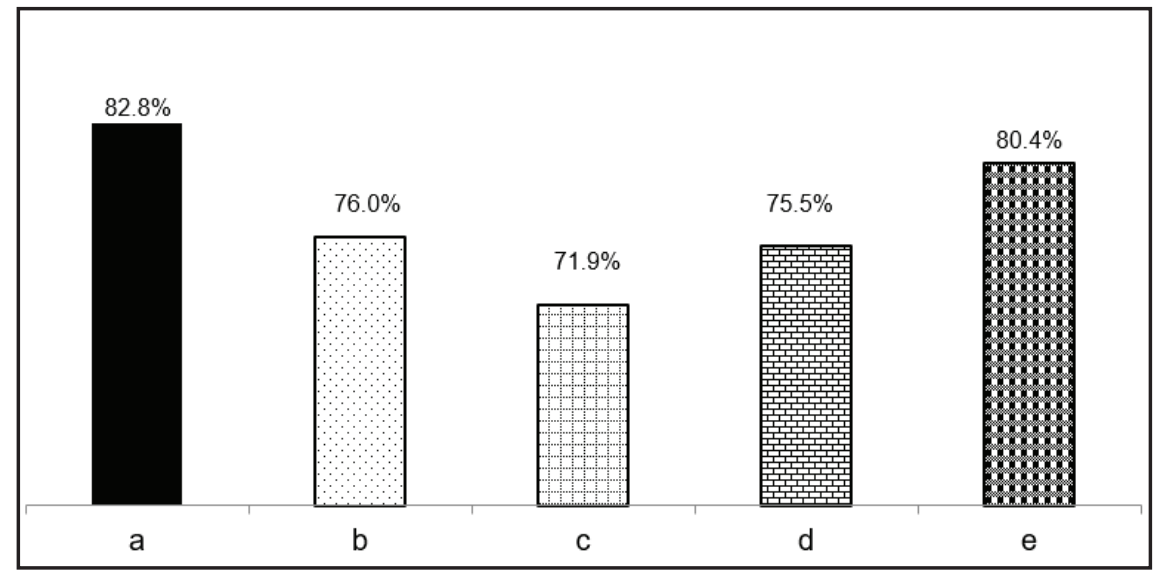

Figure 3. Comparison between initial characteristics of eight carrot seeds lots: germination reported on packages (a), germination test in laboratory (b) and seedling emergence test (c), with viability verified by tetrazolium tests varying cutting and contact time in solution; cutting Figure 1a during 6 and 24 h (d) and cutting Figure 1c during 2 hours (e). Bandeirantes, UENP, 2016.

Aiming to improve the methodology and reduce the execution time of tetrazolium test, the authors verified that hydration during 2 hours in filter paper rolls with combination of lateral cutting as close as possible to the embryo, without reaching it, and coloration development in $\mathrm{TZ}$ solution $(0.1 \%)$ at $35^{\circ} \mathrm{C}$ during 2 hours, showed to be efficient and safe, allowing results as reliable as the ones obtained using the standard germination test.

\section{REFERENCES}

ABCSEM. Associação Brasileira do Comércio de Sementes e Mudas. 2014. $2^{\circ}$ Levantamento de dados socioeconômicos da cadeia produtiva de hortaliças no Brasil. Available at: http://wwww. abcsem.com.br. Accessed at January 29, 2014.
ANDRADE, RNB; SANTOS, DSB; SANTOSFILHO, BG; MELLO, VDC. 1996. Testes de germinação e de tetrazólio em sementes de cenoura armazenadas por diferentes períodos. Revista Brasileira de Sementes 18: 108-116.

AOSA. Association of Official Seed Analysts and Society of Commercial Seed Technologists. 2002. Tetrazolium testing handbook. Washington: Jack Peters.

BARROS, DI; DIAS, DCFS; BHERING, MC; DIAS, LAS; ARAUJO, EF. 2005. Uso do teste de tetrazólio para avaliação da qualidade fisiológica de sementes de abobrinha. Revista Brasileira de Sementes 27: 165-171.

BHERING, MC; DIAS, DCFS; BARROS, DI. 2005. Adequação da metodologia do teste de tetrazólio para avaliação da qualidade fisiológica de sementes de melancia. Revista Brasileira de Sementes 27: 176-182.

BRASIL. Ministério da Agricultura e da Reforma Agrária. 2009. Regras para análise de sementes. Brasília: SNDA/DNDV/CLAV. $192 \mathrm{p}$.

DELOUCHE, JC; STILL, TW; RASPET, M;
LIENHARD, M.1976. O teste de tetrazólio para viabilidade da semente. Brasília: AGIPLAN. 103p.

FILGUEIRA, FAR. 2012. Novo manual de olericultura: agrotecnologia moderna na produção e comercialização de hortaliças. Viçosa: UFV. 421p.

GAGLIARDI, B; MARCOS FILHO, J. 2011. Assessment of the physiological potential of bell pepper seeds and relationship with seedling emergence. Revista Brasileira de Sementes 33: 162-170.

LIMA, CB; BELLETTINI, NMT; JANANI, JK; SILVA, AS; AMADOR, TS; VIEIRA, MAV; CHEIRUBIM, AP. 2007. Metodologias do teste de tetrazólio para sementes de melão (Cucumis melo L.) Revista Brasileira de Biociências 5: 744-746.

LIMA, LB; PINTO, TLF; NOVEMBRE, ADLC. 2010. Avaliação da viabilidade e do vigor de sementes de pepino pelo teste de tetrazólio. Revista Brasileira de Sementes 32: 60-68.

MARCOS FILHO, J. 2005. Fisiologia de plantas cultivadas. $1^{\mathrm{a} e d .}$ Piracicaba: FEALQ. 495p.

MARCOS FILHO, J; CÍCERO, SM; SILVA, WR. 1987. Avaliação da qualidade das sementes. Piracicaba: FEALQ. 230p.

MIRANDA, RM. 2015. Qualidade fisiológica, anatomia e histoquimica durante o desenvolvimento de sementes de cenoura (Daucus carota L.). Viçosa: UFV. 27p (Dissertação mestrado).

NERY, MC; CARVALHO, MLM; OLIVEIRA, LM. 2007. Teste de tetrazólio para avaliação da qualidade fisiológica de sementes de melancia. Semina 28: 365-372.

PEREIRA, RS; NASCIMENTO, WM; VIEIRA, JV. 2007. Germinação e vigor de sementes de cenoura sob condições de altas temperaturas. Horticultura Brasileira 25: 215-219.

RODO, AB; PANOBIANCO, M; MARCOS FILHO, J. 2000. Metodologia alternativa do teste de envelhecimento acelerado para sementes de cenoura. Scientia Agricola 57: 289-292.

SANTOS, MAO; NOVEMBRE, ADLC; MARCOS FILHO, J. 2007. Tetrazolium test to assess viability and vigour of tomato seeds. Seed Science and Technology 35: 213-223. 